\title{
Erratum to: Sequence stratigraphy and depositional environments of Middle-Late Miocene sediments in the eastern part of the Coastal Swamp depobelt, Niger Delta Basin, Nigeria
}

\author{
Ayonma Wilfred Mode ${ }^{1}$ - Chidozie Izuchukwu Princeton Dim ${ }^{1}$. \\ Bertram Maduka Ozumba ${ }^{2}$
}

Published online: 22 April 2015

(C) Saudi Society for Geosciences 2015

Erratum to: Arab J Geosci

DOI 10.1007/s12517-015-1798-3

The original version of this article, unfortunately, contained an error.

Co-authors Chidozie Izuchukwu Princeton Dim and Bertram Maduka Ozumba were omitted. Both authors and their affiliations are given in this article.

The online version of the original article can be found at http://dx.doi.org/ 10.1007/s12517-015-1798-3.

\footnotetext{
Ayonma Wilfred Mode

wilfred.mode77@gmail.com

Chidozie Izuchukwu Princeton Dim CHIDOZIEDIM@YAHOO.COM

Bertram Maduka Ozumba

bertram.ozumba@sbcglobal.net

1 Department of Geology, Faculty of Physical Sciences, University of Nigeria, Nsukka 410001, Enugu State, Nigeria

2 Shell Petroleum Development Company Ltd, Portharcourt, Nigeria
} 